\title{
Transitioning Non-Traditional Students To An Undergraduate Business Program
}

April E. Bailey, Shippensburg University, USA

Michael T. Marsh, Shippensburg University, USA

\begin{abstract}
This paper reports experiences of non-traditional students in a specially designed section of seminar course which was primarily designed for first-year traditional business students. The College of Business's BSN101, Foundations of Business Administration (FBA), is designed to serves as a course to assist the students with transitioning into the business program. Typical traditional classes have enrollments of about 80 students. The special section for non-traditional students had seven students, 24 years of age or older, who were returning to undergraduate business school. This paper reports results of the implementation of the new program design in the FBA classes. Results are important not only to the College of Business, but also to the other Colleges as interest in first-year seminar courses and better serving the needs of non-traditional student increases. Currently, the University Retention Committee and the First-Year Seminar SubCommittee are exploring the possibility of implementing a first-year seminar courses in the College of Arts and Sciences and the College of Education and Human Services to be recommended to the Provost. Data collected for the experimental section in the study reported here will support decision-making regarding new seminar courses.
\end{abstract}

Keywords: Transition, First-Year Seminars, Non-traditional Students, Business Student, and Undergraduate Business Programs

\section{INTRODUCTION}

$\mathcal{J}$

he diverse backgrounds and experiences of this group of seven adult business students provided a rich source from which to gather information for the study. Students in the experimental section typically wanted to get a head start on their fall semester and were excited to be part of the research project. Students were open-minded about exploring their original transition for returning to college, their transition through the course, and the connection to their personal development. The findings are presented at the end of this paper. Details of the classroom sessions, reflection assignments, and Blackboard discussions are described in detail. Results of Exit interviews are included. This research project builds on the previous work of Marsh and Stone (2004) that describes the traditionally designed FBA course in greater detail.

\section{LITERATURE REVIEW}

The literature on the first-year seminar and traditional-aged students is descriptive on the seminars purposes, content, and processes (Anderson, Gardner, \& Kuh, 2006; Swing, 2001; Tobolowsky, Cox, \& Wagner, 2005; Upcraft, Gardner, Barefoot, \& Associates, 2005) or program assessments (National Resource Center for the First-Year Experience and Students in Transition, 2009). One notable 35-year study (1966-2002) completed by Astin et al. (2002) showed aspects which promote the first-year seminar and how important it was for student adjustment and transition to be tied to active learning in order for students to be successful in college.

What has not been extensively explored is the adult learner in the context of a first-year seminar course; in fact, only three empirical articles exist in this area (Bailey, 2009; Hatch, 2003; Julian, 2001; Welch, 2004). Only a small amount of information is known about the adult first-year student's transition to an undergraduate degree program. Also scant in the literature is the adult undergraduate business student experience in a first-year seminar course. 
First, education consistently has learner-centeredness as a key component to adult student learning. Due to the increase of adult students, colleges and universities need to consider redesigning programs and services to meet the needs of these students. An underlying assumption from the literature is that "colleges and universities cannot continue with business-as-usual" (Apps, 1981) for the increasing number of adult students returning to undergraduate programs. Universities and colleges may want to consider learning more about their adult student demographics, characteristics, and needs for special resources and services. Adult education advocates for the uniqueness of adult's learning. Adult students have vast amounts of experiences they bring to the classroom (Knowles, 1973). They want to apply what they are learning to their real life.

Second, the higher education literature on undergraduate students suggests that student engagement and building relationship is a crucial component in adult learning. The literature suggests that in-class learning time and interactions with faculty have a powerful influence on an adult's campus experience and personal development. Other authors are in agreement by suggesting that classrooms are the center stage for adult learning (Bean \& Metzner, 1985; Kasworm \& Marienau, 1997). Students will become connected with their college if they feel the institution cares about them and their success.

\section{OVERVIEW OF THE ACTION RESEARCH PROCESS}

Action research is an on-going, non-linear spiral of knowledge (Mertler, 2009) and as the class sessions unfolded so did a cyclical pattern of knowledge creation - a curriculum for adult business students. Student responses to the Critical Incident Questionnaire (CIQ) enabled identification of specific learning needs or requests for more information on a certain topic, Responses also indicated needs for adjustments to the original syllabus for the remainder of the class sessions (See Appendix). Students anonymously completed their responses to the six questions after each class session; their responses were used to make changes as needed to the remaining class meetings. This evolving design was consistent with the action research process and demonstrated some important findings for educators and administrators who work with adult students.

Dialog with each student began prior to the summer course. The course offering was listed on the University's student scheduling website and students as they were admitted to the College of Business, received a letter explaining the course and the chance to be involved with a research project. Students responded with email and phone calls in early spring as the recruiting process began and a class list of students who were interested in participating and planned to enroll in the course was developed.

\section{ACTION RESEARCH: CIRRICULUM PLANNING}

The first day of class was held in the summer on from 3:00 - 5:00 pm in the College of Business conference room. Since it was a small group, it was important to have a place to meet that was conducive of group discussion. One student was already in the room 25 minutes before class was to start. She appeared very nervous and was biting her fingernails. Introductions were made and immediately she said, "I'm really nervous. This is my first class." Efforts were made to put her at ease and ensure her that she would have a low stress, enjoyable experience and still be successful in the class. Shortly after, a second student arrived and quickly commented on frustrated she was with the registration process and shared the ten emails of "getting the run around" with administration matters. It was requested that she keep them since it is good documentation of the struggles adult students have as they return to college and attempt to register for classes. After communicating with the participants we discovered that four students did not know where to park and did not have parking permits; visitor passes for the day were provided so that they would not receive a parking ticket. With parking issues temporarily solved, we started class discussion. While discussing delivery of course material, some online, it was determined that two students had not gotten their student identification cards (campus photo ID). This prompted an immediate conversation about the need for and method to provide better information to new students. Subsequent investigation determined that while most of these administration type items are "in automatic" for traditional freshman starting in the fall, the process was found to be not as structured for mid-year and summer starts.

Requests were made by several students for a time adjustment for the class; the 3:00 pm class time was causing some hardship (with respect to taking leave from their employer). Collectively, Tuesday and Thursday's 
were good days for the class, however, one student expressed needing to quit her job or dropping the class if the class time remained 3:00-5:00 pm. Another, who was commuting from two hours of away, did not want the class to end too late. The most mutually convenient time for meeting was still Tuesday and Thursday, but we began an hour later; our class time would be 4:00-6:00 pm beginning the second week of class.

With administration issues apparently out of the way, introductions were made and the importance of the first-year seminar was explained. Incorporated into the introduction was how the class was part of research about the potential need to include a curriculum that was more tailored to the needs of adult students. General break-the-ice activities were incorporated next so that the students could begin to get to know one another. Each student was asked to discuss why they were returning to college or starting their degree program later in life, why Shippensburg University, why they were majoring in business, their general goal for the course, the number of credits they had earned, their current job title, and something about themselves - family, pets, or hobbies.

To give the students some ideas for topics that would be covered in the seminar, we reviewed the upcoming fall syllabus for the Foundations course. Students pointed out topics of particular interest and added some not in the syllabus that they thought would be useful. New topics discussed for possible inclusion were: campus tour, Career Development Center (CDC) - intervention of cover letters, résumés, and reference pages, library overview and instruction, the MBA/CPA program, and meeting College of Business staff and administration. Two additional topics (financial aid information and meeting the registrar) were mentioned but later decided by the group that either they were no longer needed or the student with the request took care of the issue(s) on their own. The group unanimously decided to keep topics from the traditionally-aged syllabus such as study plans, BlackBoard Learning System, internships, and business etiquette discussion. They elected not to have a textbook or to read Business Week, but wanted to include guest speakers on study abroad and go into greater detail on the different functional areas of business (majors). The topics which emerged from the first day of class built the foundation for the seminar as to what aspects of business we would explore, along with the topics for the students' adjustment and transition to college through the first-year seminar course. Before class ended, the students, through guided discussion, decided on the topics and agenda for the next two classes.

Announcements of campus opportunities, business club information, and the upcoming important dates for involvement in the fall semester (i.e., etiquette dinners, ice cream networking social) were distributed. A student asked how you go about changing or declaring majors; this topic seemed to be of significance interest so the process and appropriate forms were discussed.

After briefing the students on the purpose of the study, they were left alone thus giving the students privacy to decide for or against participating in the study. Consent forms for the study were distributed and delivered them to the Dean's Office where they remained in the sealed envelope until grades were given at the end of the semester. Once the students had completed the consent process, the last 45 minutes of class time was used to ensure students could log into their email, Student Information System (SIS), and Blackboard accounts.

Two students were not able to attend activities on transfer student orientation day and therefore did not get their student IDs. By not having their student IDs, both students were prohibited to access the University's on-line tools including email, SIS, and Blackboard. One of the students' main concerns was that their academic advisor was not yet listed in the SIS. This is not normally an issue the first day of classes in the fall because all paperwork has processed through by the end of August; however, with the course being offered in the summer, this was a first time this issue had surfaced. Students were assured that faculty and staff would work with the department secretaries to find out who each of their academic advisors was along with contact information for him or her. The students received an email the following day with that information. It was very interesting with respect to transition that many of the students have already started thinking about the fall schedule and two declared accounting students were already thinking about the CPA/MBA program. This level of interest in graduate programs is not typical in traditionally-aged classes.

Many important administrative tasks were accomplished in a relatively short period of time but activities that need to be completed for the actual material in the course need to be confirmed or arranged. For example, a request for a representative from the Career Development Center (CDC) to visit the students, a room at the library 
was reserved and an hour library instruction with a reference librarian arranged, and an agenda for the next two classes was posted to Blackboard. During the traditionally-aged class all these arrangements were made far in advance of the first class meeting, but that was not possible for this summer class.

This class experienced many of the same anxieties a traditionally-aged student but to a slightly higher degree. They experienced more than typical confusion during registration and they appeared to be considerable anxious about "getting everything just right" during the first day of class. An additional stress factor was the class starting time; starting class just one hour later helped temper the stress level of students. "Obvious" administrative matters such as assuming new students have their student id, attended orientation, know who their advisor is, know where to park, and are familiar with the email, SIS, Blackboard, and the University website had to be given special attention. We noted that we did not appreciate how important the campus tour would be for this group of students. No other group before this one suggested that library instruction be incorporated to the curriculum. These students were extremely enthusiastic about ice-breaking activities that introduce themselves the first day; activities like these have never been well received by students in traditionally-aged classes.

The experience of engaging students to participate in an action research project yielded its own significant learning points and offered a curriculum for future sections of the first-year seminar, FBA. While the above discussion includes observations and activities over a very short timeframe, preliminary findings of seven subsequent meetings that took place are summarized in the following section. These preliminary findings reflected the group's initial planning session (first-day of class), various classroom sessions, on-line discussion board conversations, reflective writing assignments and exit interviews.

\section{FINDINGS}

Through involving participants in the planning and activities within the class sessions, many insightful results of using an action research approach to explore adult business students' transitions to college and tailoring a first-year seminar to their needs emerged. From reviewing all reflection papers, correspondences, Blackboard online discussions, and interview transcripts for the exit interview, eleven preliminary themes emerged regarding the students reason for retuning to an undergraduate business program and their transition and development in the course. The students' primary reason for returning to an undergraduate business program was to fulfill a lifelong goal of earning a bachelor's degree. In addition, the students noted in their reflection papers and during their exit interviews that they "wanted a better life for themselves and their family." Gaining financial stability was also relevant to this group of students. A significant amount of the participants mentioned their unhappiness in their current career and a need to increase skills and their knowledge of technology. A profound number of students were candid about their apprehension to return to school. In their own ways, they mentioned lack of confidence, fear, and low self-esteem. However, what the students explained was "that it was their time to return"; almost as if it was the right time and everything was aligning in their life for them to finally complete their education goals. This was not without support from family, faculty, administrators, colleagues, employers, and friends. Every student in the study mentioned the importance of having support, some identified financial support while others noted emotional support such as encouragement, family members providing child care service or delivery of meals.

Students reported that two of the main ways in which their adjustment to college life was aided were having a student advocate for adult learners, and enrolling in the FBA course in the summer term in order to better prepare for the fall semester by helping them become organized. Students liked being in a smaller class and a large majority of them referred to it as "the one-on-one FBA class." While it was not intended to be part of the research, students perceived a sense of fellowship had developed among the participants in the class. Halfway through the four week summer semester, students were comparing their fall semesters and finding out which classes they would have with other members of the class. Some of the participants of the study, who had full-time positions, mentored the younger adult students who were thinking of going into similar careers as those who were in permanent, fulltime positions.

Students mentioned feeling a sense of being part of the college by meeting the associate dean and his administrative assistant. The associate dean told all the students to come to his office for a College of Business tshirt; he found not only the size shirt that was requested by each student but allowed them to choice a color (blue or 
red) which are the University colors. Not only were the students delighted to have this visit, they were elated with their new gift that connected them to the University. The group suggested a class photo. That they all want to wear their College of Business t-shirt captured the connection that the students were beginning to feel to the college.

Lastly, it was undoubtedly a transitional experience for this group of students. During the exit interviews the top four benefits of the class were evident. They were:

- $\quad$ having a small class size,

- $\quad$ having the course immediately preceding the semester they planned on enrolling,

- $\quad$ having an advocate for adult learners, and

- $\quad$ engaging in an action research project to help develop a curriculum for future adult learners.

\section{CONCLUSION}

The motivation for the adult students returning to school seemed to be very different than that of the traditional student. They were returning to school with very specific goals and expectations, and also with more anxiety. Some were returning for financial reasons, others in order to advance within a career field or to pursue a new career field, and most mentioned to fulfill a life goal. When the syllabus for the standard First-Year Seminar was presented to the adult students, they felt that the course content would not be adequate to meet their individual needs. All felt that a large portion of the curriculum was irrelevant to them as adult learners and most proposed additions to the curriculum that would be more beneficial to them as adult learners. Also, it was especially helpful for each student to become acquainted with similarly situated students and a faculty member who understood each of their unique situations. This allowed them to create a social network within the school for which they could turn to for support and advice. All of the students in this section of the course were enthusiastic to have the opportunity to be part of this course that was so accommodating to their unique needs. Undoubtedly, adult students need a different experience with respect to first-year seminar. As researchers, we have gained an appreciation for the dedication required of an adult student who makes the decision to return to college to complete their education. The choice requires the rearrangement of every other aspect in their life, and it requires them, as well as their families, to make significant sacrifices in order for them to make the choice possible.

\section{FUTURE RESEARCH}

The opportunities to build upon this study are immense. The findings of the research illustrate that there is still much to learn about what adult students need in returning to higher education regarding campus resources and activities as well as a first-year seminar program and orientation program. As an under-researched population, adult business students present a demographic ripe for further in-depth research concerning their personal and professional development. Also, business education can learn much from this study's application of action research to engage students in learning, adjustment, and development. Action research is not widely utilized within adult or business education, and this study provides an opportunity where the concerns and experiences of adult business students were a focal point of the research. Today, traditional business classes are still taught from more of a behaviorist philosophy of education and a teacher-centered methodology. Completing a follow-up study of the seven participants is planned for the future.

Several recommendations for future research stem from this study. First, evaluations of the first-year seminar programs and services for adult undergraduate students could be extended to colleges where students are not only majoring in business. Other colleges and universities may want to learn how their student body perceives their own campus programs and resources. Further research in this area could lead to finding model programs for first-year seminars or orientation programs for adult learners. Second, the research undertaken in this study has broken new ground for researchers focusing on the first-year seminar experience of adult undergraduate students at institutions of higher education. Fourth, this study could be replicated to include people of color and other minorities. This would enhance educational institution understanding of a more diverse group in terms of race, ethnicity, class, and gender for a more in-depth understanding of these groups regarding their first-year seminar or orientation experience. Fifth, a larger group of participants based on the primary findings of this study may serve to validate adult business students' apprehensions of the typical first-year seminar program and orientation. Sixth, the 
relationship between adult students' learning and the interaction of faculty and student conducting research is worthy of further research. One could examine if interactions with faculty and other students is a substitute for organized participation. Seventh, an action research study of engaging students in creating a welcome packet for their university to be used during orientation or within the first-year seminar would be a follow-up to this study. Findings from these seven recommendations for further research would ultimately help modify existing programs or aid in designing new initiatives.

\section{AUTHOR INFORMATION}

Dr. April E. Bailey is an assistant professor in the John L. Grove College of Business at Shippensburg University of Pennsylvania. In 2009, she has earned her doctorate in Adult Education from The Pennsylvania State University. Her research interests are first-year students, adult learners, and academic advising.

Dr. Michael T. Marsh, a member of the Shippensburg faculty since 1991, is a Professor in Management Information Systems at the John L. Grove College of Business, Shippensburg University. His academic credentials include a B.S. in Mathematics, a M.S. in Computer Science, a MBA, and a doctorate in Operations Research. He is a university leader in the use of instructional technology and taught a variety of classes including Business Computer Systems, Computer Programming, E-business, and Instructional Technology in Education. Dr. Marsh has written and been the project director for several successful technology grants and serves on the University Infrastructure and Emerging Technology Committees.

\section{REFERENCES}

1. Anderson, C., Gardner, J. N., \& Kuh, G. D. (2006). Cultivating campus cultures that value student success. (Teleconference 2 of the Teleconference \& Webcast Series) University of South Carolina, National Resource Center for The First-Year Experience \& Students in Transition.

2. $\quad$ Apps, J. W. (1981). The adult learner on campus: A guide for instructors and administrators. Chicago: Follett.

3. Astin, A. W., Oseguera, L., Sax, L. J., \& Korn, W. S. (2002). The American freshman: Thirty-five year trends. Los Angeles: Higher Education Research Institute, UCLA.

4. Bailey, A. E. (2009). Exploring Adult Business Student's Transition to College through a First-Year Seminar Course: An Action Research Study. Doctoral Dissertation, The Pennsylvania State University.

5. Bean, J. P., \& Metzner, B. S. (1985). A conceptual model of nontraditional undergraduate student attrition. Review of Educational Research, 55(4), 485-540.

6. Hatch, C. (2003). Orienting nontraditional students to college: Creating opportunities supporting success. In J. A.Ward-Roof \& C. Hatch. Designing successful transitions: A guide for orienting students to college. (2nd ed.). University of South Carolina: National Resource Center for The First-Year Experience \& Students in Transition.

7. Julian, D. M. (2001) Evaluation of first-year seminar/orientation programs and services offered for part/full-time reentering, transfer, and first-time adult/nontraditional undergraduate students attending AAU institutions of higher education. Doctoral Dissertation, University of Pittsburgh, Retrieved April 14, 2008, from The ProQuest Digital Dissertations database. (Publication No. AAT 3026040).

8. Kasworm, C. E., \& Marienau, C. A. (1997). Principles for assessment of adult learning. New Directions for Adult and Continuing Education, 75, 5-16.

9. Knowles, M. S. (1973). The adult learner: A neglected species. Houston: Gulf Publishing Company. Revised Edition 1990.

10. Marsh, M. T. \& Stone, S. (2004). A Model for Teaching Integration of Business Disciplines to Freshman Business Majors. Journal of College Teaching and Learning, 1(1), 23-34.

11. Mertler, C. (2009) Action research: Teachers as researchers in the classroom. 2nd Edition. Thousand Oaks, CA: Sage.

12. National Resource Center for the First-Year Experience and Students in Transition. (2009). First-Year resources. Retrieved October 22, 2009, from the University of South Carolina Web site: http://www.sc.edu/fye 
13. Swing, R. L. (Ed.). (2001). Proving and improving: Strategies for assessing the first-year (Monograph No. 33). Columbia, SC: University of South Carolina, National Resource Center for The First-Year Experience and Students in Transition.

14. Tobolowsky, B. F., Cox, B. E., \& Wagner, M. T. (Eds.). (2005). Exploring the evidence; reporting research on fist-year seminars, volume II (Monograph No. 42). Columbia, SC: University of South Carolina, National Resource Center for The First-Year Experience and Students in Transition.

15. Upcraft, M. L., Gardner, J. N., Barefoot, B. O., \& Associates. (2005). Challenging \& supporting the firstyear student: A handbook for improving the first year of college. San Francisco: Jossey-Bass.

16. Welch, B. (2004). The perspectives of non-traditional students regarding a first-year orientation program. (University of New Orleans). 


\section{APPENDIX A}

\section{Critical Incident Questionnaire (CIQ)}

Please respond to the following questions at the end of class. You may refer to the class discussions, readings, guest speakers, and activities that occurred during this week's classes. You may answer with short phrases if you wish.

1. A time in class that I felt most engaged was...

2. A time in class that I felt least engaged was ...

3. The thing that surprised me the most was ...

4. The most important thing I learned was...

5. The thing I hoped we would talk more about was...

6. What I hope we will talk about in future classes... 